Prepared in cooperation with the National Park Service

Reconnaissance of Mercury and Methylmercury in the St. Croix River and Selected Tributaries, Minnesota and Wisconsin, July 2000 through October 2001

Water-Resources Investigations Report 03-4223 


.

. 


\section{Reconnaissance of Mercury and}

Methylmercury in the St. Croix River and Selected Tributaries, Minnesota and Wisconsin, July 2000 through October 2001

By G.A. Payne and D.S. Hansen

Water-Resources Investigations Report 03-4223

Prepared in cooperation with the National Park Service 


\section{U.S. DEPARTMENT OF THE INTERIOR}

Gale A. Norton, Secretary

\section{U.S. GEOLOGICAL SURVEY}

Charles G. Groat, Director

Use of firm, trade, and brand names in this report is for identification purposes only and does not constitute endorsement by the U.S. Geological Survey.

Mounds View, Minnesota, 2003

For additional information write to:

U.S. Geological Survey

District Chief

2280 Woodale Drive

Mounds View, MN 55112

Copies of this report can be purchased from:

\section{U.S. Geological Survey}

Branch of Information Services

Box 25286, MS 517

Federal Center

Denver, CO 80225

Information regarding the USGS is available on the Internet via the World Wide Web.

You may connect to the USGS Home Page using the Universal Resource Locator (URL) at http://wwwrvares.er.usgs.gov.

You may also connect to the Minnesota District Home Page at http://mn.water.usgs.gov/.

For more information on all USGS reports and products (including maps, images, and computerized data), call 1-888-ASK-USGS

Water-Resources Investigations Report 03-4223 


\section{Contents}

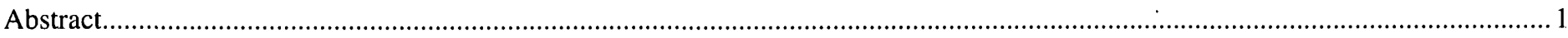

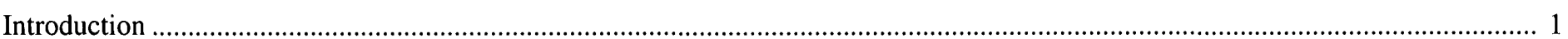

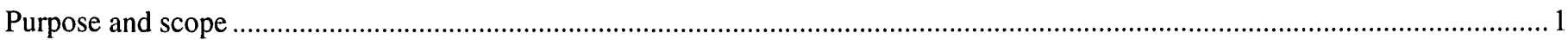

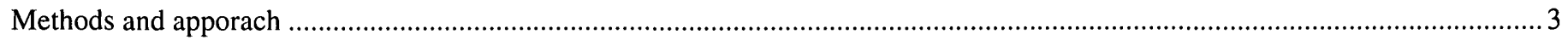

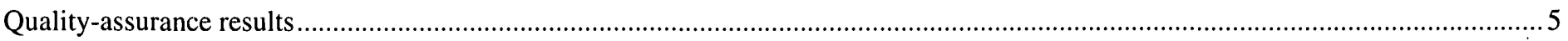

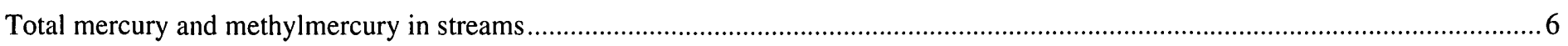

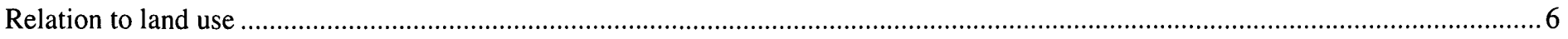

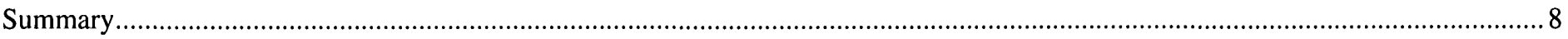

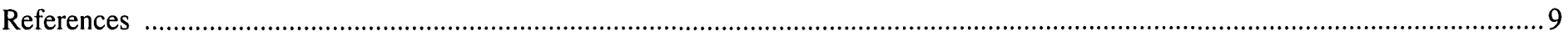

\section{Illustrations}

Figure 1 Map showing hydrology and locations of selected towns, cities and sites in the St. Croix River Basin where

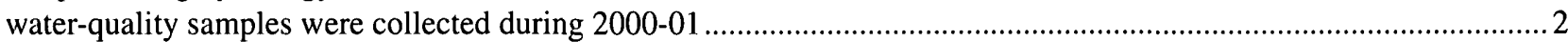

Figures 2-3. Graphs showing:

2. Concentrations, loads, and yields of total mercury and methylmercury in the St. Croix River Basin during 2000-01

3 Total mercury, methylmercury, and stream discharge for the Namekagon River near Leonards, Wisconsin in the St. Croix River Basin, May-October, 2001

\section{Tables}

1. Sampling sites, drainage basins, and land-use type, St. Croix River Basin, Minnesota and Wisconsin, 2000-01 3

2. Sampling sites and analytical chemistry results, St. Croix River Basin, Minnesota and Wisconsin, 2000-01 4

3. Results of analyses for quality-assurance replicate samples and blanks collected in the St. Croix River Basin, Minnesota and Wisconsin, 2000-01

\section{Conversion Factors and Water Quality Units}

$\begin{array}{rll}\text { Multiply inch-pound unit } & \text { By } & \text { To obtain metric unit } \\ \text { square kilometer }\left(\mathrm{km}^{2}\right) & 0.6214 & \text { square mile } \\ \text { cubic meter per second }\left(\mathrm{m}^{3} / \mathrm{s}\right) & 35.31 & \text { cubic meters per second }\end{array}$

Chemical concentrations are given in metric units. Chemical concentrations of substances in water are given in milligrams per liter ( $\mathrm{mg} / \mathrm{L})$ and nanograms per liter (ng/L). Milligrams per liter is a unit expressing the concentration of chemical constituents in solution as mass (milligrams) of solute per unit volume (liter) of water. Nanograms per liter is a unit expressing the concentration of chemical constituents in solution as mass (nanograms) of solute per unit volume (liter) of water. One million nanograms per liter is equivalent to one milligram per liter. 


\title{
Reconnaissance of Mercury and Methylmercury in the St. Croix River and Selected Tributaries, Minnesota and Wisconsin, July 2000 through October 2001
}

\author{
By G.A. Payne and D.S. Hansen
}

\section{ABSTRACT}

A reconnaissance-level assessment to characterize total mercury and methylmercury concentrations during summer lowflow conditions was conducted in the St. Croix River Basin during July 2000 through October 2001. Samples were collected at 6 main stem and 16 tributary sites. Loads of total mercury and methylmercury increased in the St. Croix River main stem between Nevers Dam and Franconia. Total mercury and methylmercury concentrations were greatest during July in the Namekagon River. Methylmercury yields in the Namekagon River and Rush Creek were greater than the yield for other tributary streams. Methylmercury concentrations and yields were greater in tributaries draining wetland/forest watersheds than in tributaries draining agricultural/forest watersheds.

\section{INTRODUCTION}

The St. Croix River Basin drains $4,822 \mathrm{~km}^{2}$ in Minnesota and Wisconsin (fig. 1). The St. Croix National Scenic Riverway (Riverway) was established in 1968 as one of the original components of the Wild and Scenic Rivers Act. The portion of the St. Croix River downstream of Taylors Falls, Minnesota to the confluence with the Mississippi River was added to the system in 1972 (fig. 1). Recreational opportunities such as boating and canoeing attract nearly one million visitors to the Riverway annually (National Park Service, 1995).

Mercury is a ubiquitous environmental contaminant and comes from many natural and anthropogenic sources.

Atmospheric deposition and naturally occurring minerals are possible sources of mercury, but various land-use and land-cover types also may contribute disproportionate amounts of methylmercury to aquatic ecosystems. Typically, mercury occurs in very low concentrations in surface waters, in both inorganic and organic forms. Inorganic mercury is not particularly toxic, but under certain conditions can be converted to organic mercury (methylmercury), a potent neuro toxin by bacterially mediated methylation and assimilated by aquatic organisms and magnified in the food chain (Krabbenhoft and Rickert, 1995). Small amounts of inorganic mercury can cause problems in aquatic ecosystems when conditions are suitable for methylation, which primarily occurs as a by-product of bacterially-mediated sulfate reduction.

Methylmercury is a potent form of organic mercury and is among the most toxic and widespread contaminants affecting the Nation's aquatic ecosystems (Brumbaugh and others, 2001). Methylation and bioaccumulation of mercury pose toxicological risks to both fish (Wiener and Spry, 1996) and humans (U.S. Environmental Protection Agency, 1997). Because of serious concerns about methylmercury toxicity, the U.S. Environmental Protection Agency recently reduced the recommended standard for methylmercury in fish tissue from 0.5 milligram per kilogram to 0.3 milligram per kilogram (U.S. Environmental Protection Agency, 2001). Methylmercury contamination also has caused many states, including Minnesota, to issue human-health advisories for fish consumption.

Mercury has been detected in fish and mussel tissue in specimens collected from the St. Croix National Scenic Riverway. A fish-consumption advisory is currently in place in the St. Croix River Basin.

\section{PURPOSE AND SCOPE}

Information is needed on occurrence and variability of mercury in streams of the St. Croix River Basin. To address this need, the U.S. Geological Survey (USGS), in cooperation with the National Park Service conducted a reconnaissance-level assessment. This report describes results of a reconnaissance-level assessment of concentrations of mercury and methylmercury during summer low-flow conditions for the main stem of the St. Croix River and selected tributaries, the loads of mercury transported in the tributaries and in the main stem, and the yield of mercury from selected subbasins. Samples were collected from July 2000 through October 2001. The report also presents the land use associated with each tributary basin such as percent forest, wetland, and agriculture. 


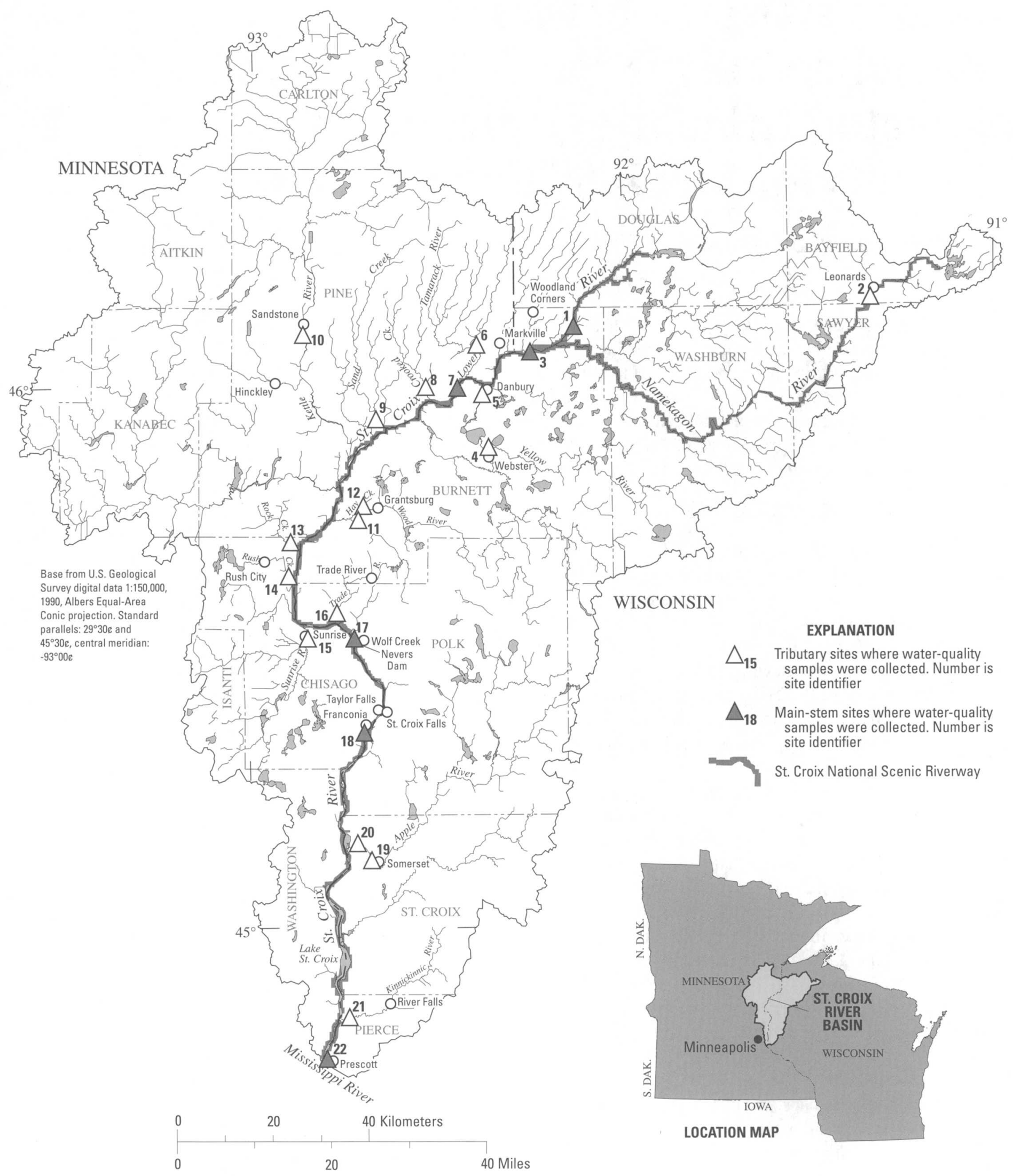

Figure 1. Hydrology and locations of selected towns, cities and sites in the St. Croix River Basin where water-quality samples were collected during 2000-01. 
A reconnaissance-level assessment of total mercury and methylmercury concentrations will provide baseline distribution information of mercury and methylmercury concentrations in the St. Croix River and can be used by resource managers to assess the threat to human health and to aquatic health of the St. Croix River Basin.

\section{METHODS AND APPROACH}

Mercury occurs in low concentrations in water, and may be present in low concentrations in the atmosphere and on surfaces near or in the sampling and processing environment. Precautions are necessary during sample collection such that exposure of the water sample to different collection containers, humans, and the atmosphere must be minimized. For the study described in this report, two-person ultra-clean sampling procedures (U.S. Environ- mental Protection Agency (USEPA) Method 1669 (U.S. Environmental Protection Agency, 1996a)) were used to collect the water samples analyzed for mercury constituents. The collectors wore disposable shoulder-length polyethylene gloves, and wrist-length latex gloves. Sample bottles were contained with double polyethylene bags, and any materials and containers that contacted the sample water were cleaned following procedures outlined by Olson and DeWild (1999).

Water samples were collected from 6 sites located on the St. Croix River main stem and from 16 tributary streams (fig. 1). Tributary watershed size ranged from 12 to $2,252 \mathrm{~km}^{2}$ and differed in land use such as forest, wetland, and agriculture (table 1).

Selected sites were sampled once during summer low flow (July 23-27, 2001) (table 2), when biological growth and mercury methylation were expected to be at seasonal maxima. The Namekagon River at Leonards, Wisconsin was sampled six times from May through October 2001 to observe mercury concentration changes at various summer and fall streamflow conditions (table 2). Quality-

assurance/quality-control samples were collected to assess precision and accuracy of collected data. Three sets of replicate samples and three fieldequipment blanks were collected and analyzed for mercury and organic-carbon constituents (table 3 ).

Whole water samples were collected and analyzed for total mercury, methylmercury, and total organic carbon. Samples were collected by dipping sample-collection bottles at 3-5 equally-spaced points in the stream cross section. Temperature, specific conductance, $\mathrm{pH}$, dissolved oxygen,

Table 1. Sampling sites, drainage basin, and land-use type, St. Croix River Basin, Minnesota and Wisconsin, 2000-01

[Main stem sites in bold; $\mathrm{km}^{2}$, square kilometers; watershed designation from Hurley and others, 1995]

\begin{tabular}{|c|c|c|c|c|c|c|}
\hline \multirow{2}{*}{$\begin{array}{l}\text { Site num- } \\
\text { ber }\end{array}$} & \multirow{2}{*}{ Site name } & \multirow{2}{*}{$\begin{array}{c}\text { Drainage } \\
\text { area }\left(\mathrm{km}^{2}\right)\end{array}$} & \multirow{2}{*}{$\begin{array}{l}\text { Watershed } \\
\text { designation }\end{array}$} & \multicolumn{3}{|c|}{ Land use (in percent) } \\
\hline & & & & Agriculture & Forest & Wetland \\
\hline 1 & St. Croix River near Woodland Corner, Wisconsin & 1,122 & Wetland/forest & 1 & 86 & 9.6 \\
\hline 2 & Namekagon River at Leonards, Wisconsin & 333 & Wetland/forest & 1.8 & 78 & 12.4 \\
\hline 3 & St. Croix River near Danbury Wisconsin & & & & & \\
\hline 4 & Yellow River at State Highway 35 near Webster, Wisconsin & 695 & Agriculture/forest & 29 & 57 & 4.6 \\
\hline 5 & Yellow River at State Highway 35 at Danbury, Wisconsin & 821 & Agriculture/forest & 23 & 56 & 11 \\
\hline 6 & Lower Tamarack River near Markville, Minnesota & 470 & Wetland/forest & 3.7 & 75 & 21 \\
\hline 7 & $\begin{array}{l}\text { St. Croix River at State Highway } 77 \text { near Danbury, } \\
\text { Wisconsin }\end{array}$ & & & & & \\
\hline 8 & Crooked Creek near Hinckley, Minnesota & 244 & Agriculture/forest & 18.6 & 66 & 14 \\
\hline 9 & Sand Creek near Hinckley, Minnesota & 284 & Agriculture/forest & 23.3 & 64 & 14 \\
\hline 10 & Kettle River below Sandstone, Minnesota & 2,252 & Agriculture/forest & 27 & 53 & 18 \\
\hline 11 & Wood River at State Highway 70 near Grantsburg, Wisconsin & 414 & Agriculture/forest & 44 & 27 & 24 \\
\hline 12 & Hay Creek near Grantsburg, Wisconsin & 12 & Agriculture/forest & 30 & 48 & 17 \\
\hline 13 & Rock Creek near Rush City, Minnesota & 116 & Agriculture/forest & 72 & 10 & 16 \\
\hline 14 & Rush Creek near Rush City, Minnesota & 147 & Agriculture/wetland & 52 & 16 & 20 \\
\hline 15 & Sunrise River at Sunrise, Minnesota & 824 & Agriculture/wetland & 54 & 8.3 & 22 \\
\hline 16 & Trade River near Trade River, Wisconsin & 345 & Agriculture/forest & 33 & 37 & 12 \\
\hline 17 & St. Croix River at Nevers Dam site near Wolf Creek, Wisconsin & & & & & \\
\hline 18 & St. Croix River at Franconia, Minnesota & & & & & \\
\hline 19 & Apple River above 05341499 at park in Somerset, Wisconsin & 1,427 & Agriculture/forest & 61 & 29 & 7.1 \\
\hline 20 & Apple River near Somerset, Wisconsin & 1,427 & Agriculture/forest & 61 & 29 & 7.1 \\
\hline 21 & Kinnickinnic River near River Falls, Wisconsin & 449 & Agriculture & 92 & 4.6 & 0.0 \\
\hline 22 & St. Croix River at Prescott, Wisconsin & & & & & \\
\hline
\end{tabular}

'Christopher A. Sanocki, U.S. Geological Survey, written commun., 2003. 


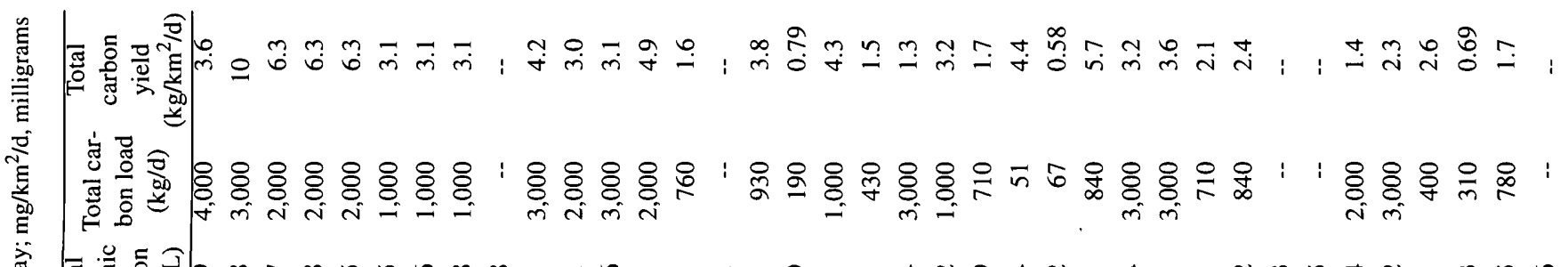

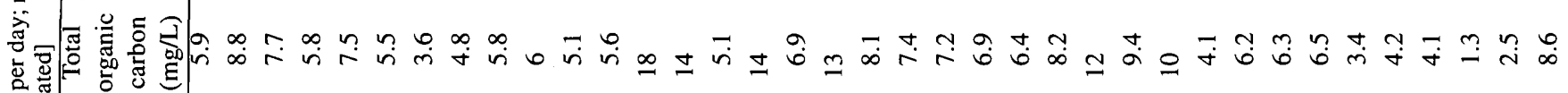

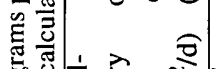

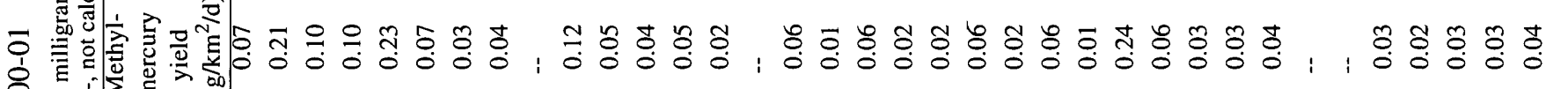

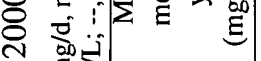

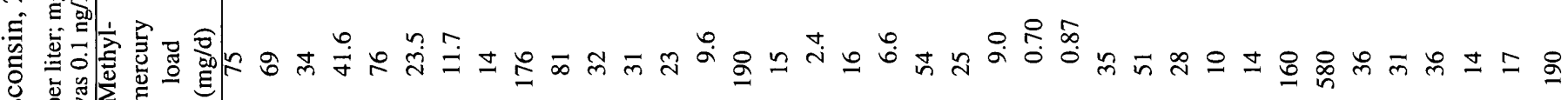

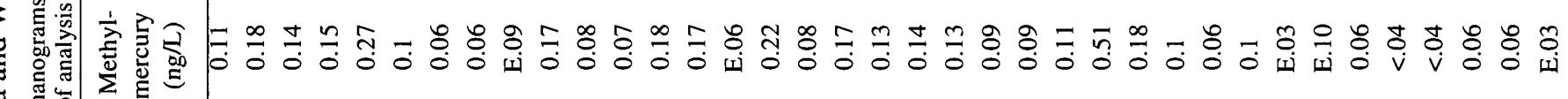

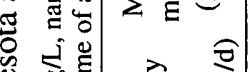

至

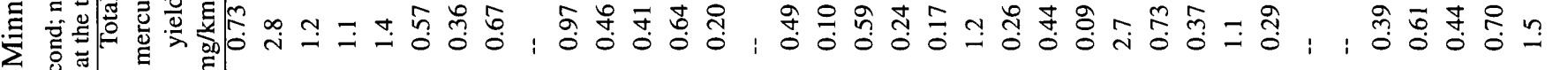

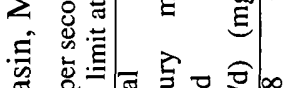

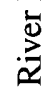

范

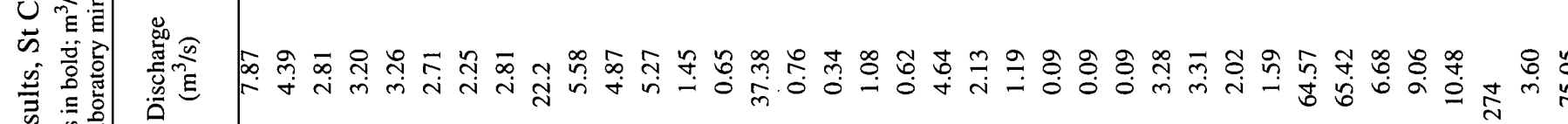

\section{,}

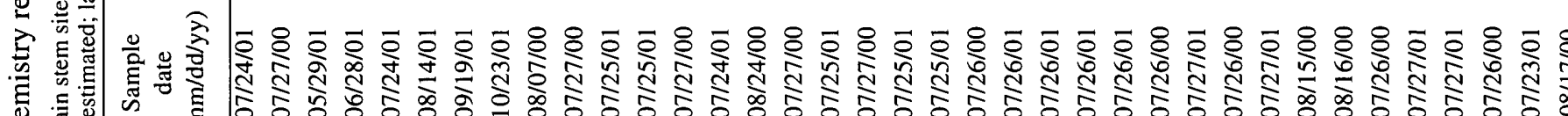

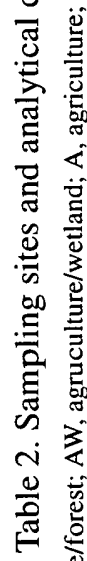

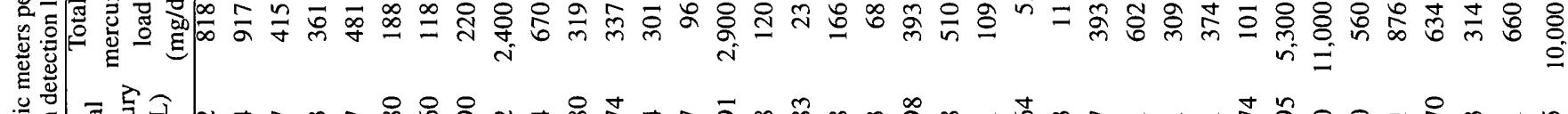

$\approx \frac{0}{\sigma}$

$\stackrel{\infty}{\infty} \stackrel{\infty}{=}$

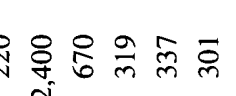

\& 8

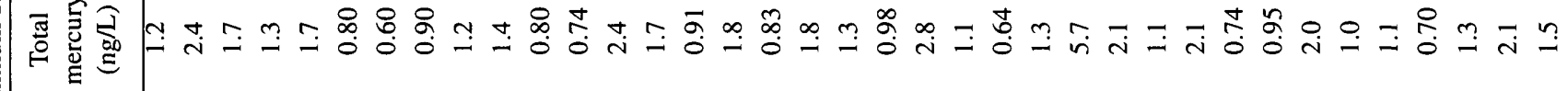
思 
and turbidity were measured in the stream using portable field instruments according to procedures described in Wilde and Radtke (1998).

Instantaneous stream discharge was determined at the time of sample collection. Discharge at ungaged streams (16 sites) was determined by current-meter measurements (Buchanan and Somers, 1969). Stream discharge at two of the sampling sites was determined by application of stagedischarge relations developed for USGS gaging stations located at those sites. Stream discharge for one site (Apple River near Somerset, Wisconsin) was determined using a powergeneration turbine rating that is periodically verified by field measurements made by USGS personnel.

Water samples were processed and analyzed for mercury, methylmercury, and total organic carbon by the USGS Mercury Laboratory in Middleton, Wisconsin. This laboratory is a class100 clean-room facility, and qualityassurance procedures are available at URL http://infotrek.er.usgs.gov/doc/mercury/. Total mercury concentrations were determined using USEPA method 1631(U.S. Environmental Protection Agency, 1996b) as modified by Olson and DeWild (1999). Methylmercury concentrations were determined using methods described in DeWild and others (2002). Total organic carbon concentrations were determined using a carbon analyzer (model 1010, OI Analytical, College Station Texas) using Standard Method 5310D (American Public Health Association and others, 1998).

Methylmercury load (mg/d) was determined by multiplying the instantaneous stream discharge $\left(\mathrm{m}^{3} / \mathrm{s}\right)$ by the methylmercury concentration (ng/L), and by a conversion factor (86.4). Total mercury load (mg/d) was determined by multiplying the instantaneous stream discharge $\left(\mathrm{m}^{3} / \mathrm{s}\right)$ by the total mercury concentration (ng/L) and a conversion factor (86.4). The methylmercury and total mercury yield $\left(\mathrm{mg} / \mathrm{km}^{2} / \mathrm{d}\right)$ was determined by the

Table 3. Results of analyses for quality-assurance replicate samples and blanks collected in the St. Croix River Basin, Minnesota and Wisconsin, 2000-01.

[ng/L, nanograms per liter; $\mathrm{mg} / \mathrm{L}$, milligrams per liter; CV, coefficient of variation; <, less than]

\begin{tabular}{lccc}
\hline \multicolumn{1}{c}{ Kettle River below Sandstone, Minnesota } & $\begin{array}{c}\text { Total } \\
\text { mercury (ng/L) }\end{array}$ & $\begin{array}{c}\text { Methyl- } \\
\text { mercury } \\
(\mathrm{ng} / \mathrm{L})\end{array}$ & $\begin{array}{c}\text { Total organic } \\
\text { carbon } \\
(\mathrm{mg} / \mathrm{L})\end{array}$ \\
\hline Sample 1 & 0.98 & 0.135 & 7.383 \\
Sample 2 & 1.04 & 0.092 & 7.471 \\
Sample 3 & 0.95 & 0.159 & 7.390 \\
CV (percent) & 4.6 & 18 & 0.6 \\
\hline \multicolumn{1}{c}{ Rock Creek near Rush City, Minnesota } & & & \\
\hline Sample 1 & 1.30 & 0.106 & 8.175 \\
Sample 2 & 1.05 & 0.112 & 8.176 \\
Sample 3 & 1.12 & 0.109 & 7.999 \\
CV (percent) & 11 & 2.8 & 1.3 \\
\hline Lower Tamarack River near Markville, Minnesota & & & \\
\hline Sample 1 & 2.41 & 0.182 & 18.36 \\
Sample 2 & 2.65 & 0.212 & 18.66 \\
Sample 3 & 2.43 & 0.139 & 18.35 \\
CV (percent) & 5.3 & 21 & 1.0 \\
Blank 1 (August 2000) & 0.08 & $<0.007$ & 0.02 \\
Blank 2 (July 2001) & 0.06 & $<0.040$ & 0.023 \\
Blank 3 (July 2001) & 0.05 & $<0.040$ & 0.000 \\
\hline
\end{tabular}

ratio of the constituent load $(\mathrm{mg} / \mathrm{d})$ and the basin area $\left(\mathrm{km}^{2}\right)$.

\section{QUALITY-ASSURANCE RESULTS}

The USGS Mercury Laboratory in Middleton, Wisconsin routinely quantifies total mercury in USGS standard reference water samples to within 7 percent of accepted values (Farrar, 1998, 1999a and b; Farrar and Chleboun, 1999). No such reference standards exist for methylmercury in water. Coefficient of variation (CV) for replicate sample sets ranged from 4-11 percent (table 3). For methylmercury, CV ranged from 2.8-21 percent, which represents good precision for low concentration samples (less than 10 times the method detection limit of $0.025 \mathrm{ng} / \mathrm{L}$ ).

Total mercury concentrations in blank samples (table 3 ) ranged from 0.05-0.08 ng/L, whereas concentrations in stream samples ranged from 0.60-5.7 ng/L (table 2). Sample contamination, therefore, potentially could comprise about 12 percent of total mercury at the low end of the range, and as much as 5 percent in samples that had total mercury concentrations near the mean concentration of $1.5 \mathrm{ng} / \mathrm{L}$.

Methylmercury concentrations in blank samples were reported as $<0.007 \mathrm{ng} / \mathrm{L}$ in 2000 , and $<0.040 \mathrm{ng} / \mathrm{L}$ in 2001 . The lack of methylmercury concentrations greater than the minimum reporting limit (MRL) in blank samples provides reasonable assurance of an absence of bias from sample contamination. Bias from sample contamination cannot be ruled out, however, because the MRL adopted in 2001 $(0.040 \mathrm{ng} / \mathrm{L})$ is about 33 percent of the mean methylmercury concentration $(0.122 \mathrm{ng} / \mathrm{L})$ in stream samples. 


\section{TOTAL MERCURY AND METHYLMERCURY IN STREAMS}

Total mercury concentrations (table 2) ranged from 0.60 to $5.7 \mathrm{ng} / \mathrm{L}$ in the St. Croix River Basin with little indication of regional differences or consistent spatial distribution. Total mercury concentration in water from Rush Creek (site 14) was substantially greater $(5.7 \mathrm{ng} / \mathrm{L})$ than concentrations at the other sites, which ranged from 0.60-2.8 ng/L. Total mercury concentrations at each site sampled more than once commonly varied over time, but less than an order of magnitude. Brigham (2002) found large mercury concentrations in sediment collected near site 14 compared to other sites in the St. Croix River Basin.

Total mercury loads computed for the St. Croix River main stem sites ranged from 818-11,000 milligrams per day (table 2). Water from all mainstem sites was collected and analyzed in August 2000. Total mercury loads computed for the St. Croix River tributary sites ranged from 5.1 to 917 milligrams per day. The large loads at the main stem sites reflect the greater discharge at those sites relative to the tributary sites. Total mercury load increased from 2,400 to 5,300 milligrams per day from main stem site 3 to main stem site 17 , and discharge increased by $42.37 \mathrm{~m}^{3} / \mathrm{s}$. Total mercury load increased again from 5,300 to 11,000 , between site 17 and 18 ; however, streamflow increased by only $0.85 \mathrm{~m}^{3} / \mathrm{s}$. The increase in mercury load is unusual because no large tributary streams enter the main stem between sites 17 and 18 and the intervening drainage area is small $\left(738 \mathrm{~km}^{2}\right)$. The increase in total mercury load from site 17 to site 18 is nearly equal to the total mercury load accumulated in the main stem from the headwaters to site 17 .

Methylmercury formed 3-16 percent of total mercury concentrations in samples from tributary sites, and onehalf of those samples contained 7-10 percent methylmercury. At main stem sites methylmercury was 2-10 percent of the total mercury. Methylmercury concentration in samples from Rush Creek (site 14) was greater than concentrations at other sites (table 2).

The methylmercury concentrations from the St. Croix River Basin (except at site 14) are typical of streams in the Upper Midwest (Hurley and others, 1995). Methylmercury concentrations are greater in tributaries draining the northern part of the St. Croix River Basin compared to tributaries in the southern part (fig. 2).

With the exception of St. Croix River at Franconia (site 18), methylmercury load at main-stem sites ranged from 75 to $190 \mathrm{mg} / \mathrm{d}$. The methylmercury load of $580 \mathrm{mg} / \mathrm{d}$ at site 18 cannot be explained by a corresponding increase in stream discharge. Discharge at main stem sites 17,18 , and 22 were similar and ranged from $64.57 \mathrm{~m}^{3} / \mathrm{s}$ to $75.05 \mathrm{~m}^{3} / \mathrm{s}$. Unlike total mercury loads, methylmercury loads did not increase because of increased discharge. There was an increase in methylmercury load from site 17 to 18 , then a decrease to site 22 , which may indicate 5 transport of methylmercury in the main stem.

Results of monthly sampling at the Namekagon River (site 2) (fig. 3) indicate that samples collected in the St. Croix River Basin during July represent summer maximum concentrations. Based on results from site 2, sampling conducted during July 2001 coincided with the occurrence of maximum summer concentrations of both total mercury and methylmercury (table 2). Some of the seasonal variability may be related to streamflow magnitude. Total mercury and methylmercury concentrations were positively correlated with streamflow at site 2. Hurley and others (1995) proposed that pore waters in wetlands are displaced during high flows, resulting in transport of total mercury that is bound to total organic carbon. The peak total mercury and methylmercury concentrations for site 2 were measured during recession of runoffgenerated streamflow. Linear regression of total mercury concentrations and streamflow at site 2 yielded an $\mathrm{R}^{2}$ of 0.78 , and regression of total mercury concentrations and total organic carbon concentrations yielded an $\mathrm{R}^{2}$ of 0.91 .

\section{RELATION TO LAND USE}

Hurley and others (1995) sampled 39 river sites in Wisconsin during 1992-93 to determine the influences of watershed characteristics on mercury levels. Hurley grouped the watersheds into wetland/forest, agricultural/forest, agricultural/wetland, and agricultural designations based on the percent land use within each watershed. Hurley sampled during spring and fall for total mercury and methylmercury concentrations within each watershed designation to assess the effects of land use and land cover. Hurley and others (1995) reported greater yields of methylmercury in streams draining wetland/forest designations compared to other watershed designations.

Total mercury and methylmercury yields (table 2) varied widely among the St. Croix River Basin tributary watersheds sampled for this report. Total mercury yields, relative to other sites, were elevated at the Namekagon River (site 2), Rush Creek (site 14), and Kinnickinnic River (site 21). Methylmercury yields in the Namekagon River and Rush Creek were greater than the yields in other tributaries. Relatively high yields at some sites may indicate watersheds where environmental conditions enhance mobilization and transport of atmospherically deposited mercury and those watersheds where mercury has accumulated because of industrial use, spills, or disposal. Yields of both total and methylmercury in this report were 

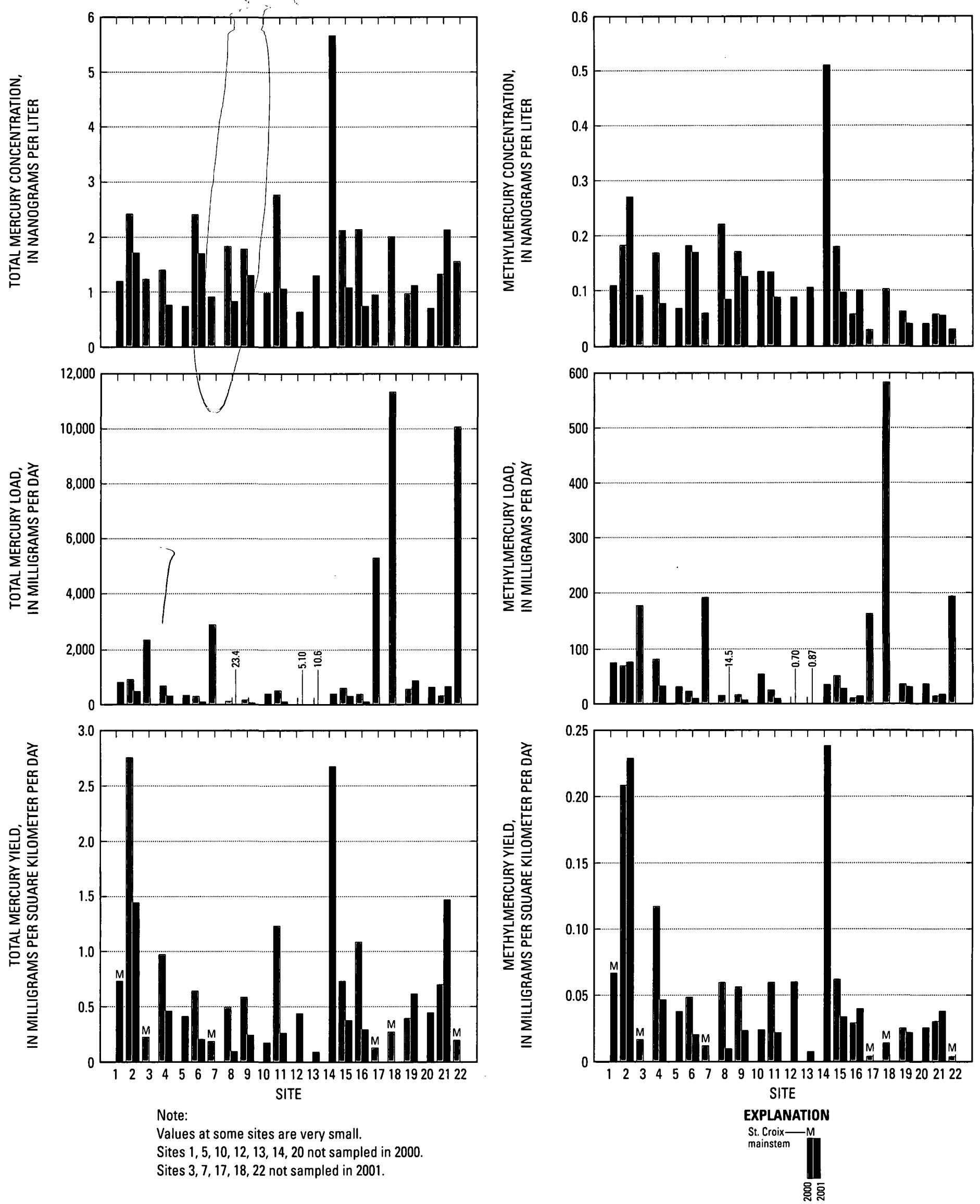

Figure 2. Concentrations, loads, and yields of total mercury and methylmercury in the St Croix River Basin during 2000-01. 


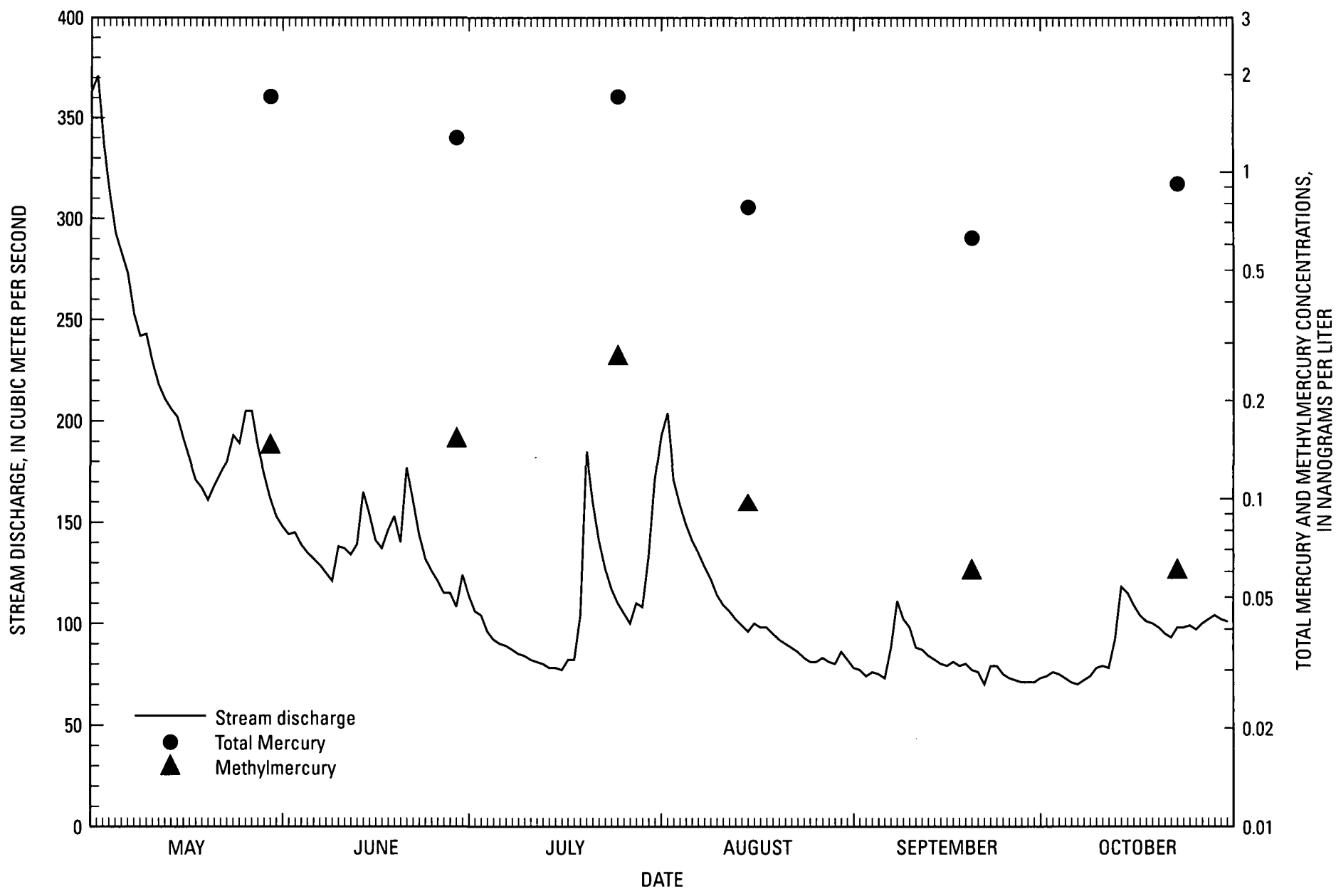

Figure 3. Total mercury, methylmercury, and stream discharge for the Namekagon River near Leonards, Wisconsin in the St Croix River Basin, May-October, 2001.

less than those reported by Hurley and others (1995), because Hurley and others sampled during spring and fall, and streams were sampled during summer low flow for this report.

\section{SUMMARY}

Samples were collected at 22 stream sites in the St. Croix River Basin during July 2000 through October 2001 to characterize total mercury and methylmercury concentrations when streams were at conditions of summer low flow. Samples were collected at 6 main stem and 16 tributary sites. The results showed some annual, within-site variability in total mercury concentrations, but regional differences in total mercury concentrations and consistent spatial patterns were not evident. Concentrations of total mercury and methylmercury in Rush Creek were at least two times greater than concentrations at other sites. Total mercury and methylmercury concentrations were greatest during July in samples collected May-October in the Namekagon River, indicating that the basin-wide sampling conducted during concentrations and yields than tributaries draining agricultural/forest watersheds (table 2) (Wilcoxon rank sum test; $\mathrm{p}<0.05)$. ing wetland/forest watersheds had significantly greater methylmercury

July may have corresponded to a period when concentrations were near summer maximums. Total mercury concentrations in the Namekagon River were positively correlated with increased streamflow and increased total organic carbon concentrations.

Loads of total mercury and methylmercury increased in the St. Croix River main stem from Nevers Dam to Franconia. Methylmercury yields in the Namekagon River and Rush Creek were greater than the yields in other tributary streams. Total mercury concentrations and yields were compared to watershed designation wetland/forest, agriculture/forest, and agriculture. Methylmercury concentrations were greater in tributaries draining wetland/forest watersheds compared to tributaries draining agricultural/forest watersheds. 


\section{REFERENCES}

American Public Health Association, American Water Works Association, and Water Environment Federation, 1998, Standard methods for the examination of water and wastewater (20th ed.): Washington D.C., American Public Health Association, variously paged.

Brigham, M.E., 2002, Elemental chemistry of streambed sediments of the St. Croix River Basin, 2000: U.S. Geological Survey Water-Resources Investigations Report 02-4087, $19 \mathrm{p}$.

Brumbaugh, W.G., Krabbenhoft, D.P., Helsel, D.R., Wiener, J.G., and Echols, K.R., 2001, A national pilot study of mercury contamination of aquatic ecosystems along multiple gradients-Bioaccumulation in fish: U.S. Geological Survey USGS/BRD/BSR-2001-0009, 25 p.

Buchanan, T.J., and Somers, W.P., 1969, Discharge measurements at gaging stations: U.S. Geological Survey Techniques of Water Resources Investigations, book 3, chap. A8, 65 p.

DeWild, J.F., Olson, M.L., and Olund, S.D., 2002, Determination of methylmercury by aqueous phase ethylation, followed by gas chromatographic separation with cold vapor atomic fluorescence detection: U.S. Geological Survey Open-File Report 01-445, 14 p.

Farrar, J.W., 1998, Results of the U.S. Geological Survey's analytical evaluation program for standard reference samples-T-151 (trace constituents), M-144 (major constituents), N-55 (nutrient constituents), $\mathrm{N}-56$ (nutrient constituents), P-29 (low ionic strength constituents), GWT-2 (ground-water trace constituents), GWM-2 (groundwater major constituents), AMW-4 (acid mine water constituents), and Hg-25 (mercury) distributed in September 1997: U.S. Geological Survey Open-File Report 98-52, 191 p.

_ 1999a, Results of the U.S. Geological Survey's analytical evaluation program for standard reference samples-T-153 (trace constituents), M-146 (major constituents), N-57 (nutrient constituents), $\mathrm{N}-58$ (nutrient constituents), P-30 (low ionic strength constituents), GWT-3 (ground-water trace constituents), GWM-3 (groundwater major constituents), and $\mathrm{Hg}-26$ (mercury) distributed in April 1988: U.S. Geological Survey Open-File Report 98-391, $160 \mathrm{p}$.

1999b, Results of the U.S. Geological Survey's analytical evaluation program for standard reference samples-T-155 (trace constituents), M-148 (major constituents), N-59 (nutrient constituents), N-60 (nutrient constituents), P-31 (low ionic strength constituents), GWT-4 (ground-water constituents), and $\mathrm{Hg}-27$ (mercury) distributed in September 1998: U.S. Geological Survey Open-File Report 99-72, $143 \mathrm{p}$.

Farrar, J.W., and Chleboun, K.M., 1999, Results of the U.S. Geological Survey's analytical evaluation program for standard reference samples distributed in March 1999: U.S. Geological Survey Open-File Report 99-259, $166 \mathrm{p}$.

Hurley, J.P., Benoit, J.M., Babiarz, C.L., Shafer, M.M., Andren, A.W., Sullivan, J.R., Hammond, R. and Web, D.A.,1995, Influences of watershed characteristics on mercury levels in Wisconsin rivers: Environmental Science and Technology, v. 29, no. 7, p. 1867-1875.

Krabbenhoft, D.P., and Rickert, D.A., 1995, Mercury contamination of aquatic ecosystems: U.S. Geological Survey Fact Sheet FS-216-95, 4 p.

National Park Service, 1995, Interpretive prospectus-St. Croix National Scenic Riverway, Minnesota/Wisconsin: St. Croix Falls, Wisc., National Park Service.

Olson, M.L., Cleckner, L.B., Hurley, J.P., Krabbenhoft, D.P., and Heelan, T.W., 1997, Resolution of matrix effects on analysis of total and methylmercury in aqueous samples from the Florida Everglades: Fresenious Journal of Analytical Chemistry, v. 358, p. 392396.

Olson, M.L., and DeWild, J.F., 1999, Techniques for the collection and species-specific analysis of low levels of mercury in water, sediments, and biota, in Morganwalp, D.W. and Buxton, H.T., eds.,U.S. Geological Survey Toxic Substances Hydrology Pro-
gram-Proceedings of the technical meeting, Charleston, South Carolina, March 8-12, 1999, volume 2 of 3Contamination of hydrologic systems and related ecosystems: U.S. Geological Survey Water-Resources Investigations Report 99-4018B, 191$200 \mathrm{p}$.

U.S. Environmental Protection Agency, 2001, Water quality criterion for the protection of human health-Methylmercury: Office of Science and Technology, Office of Water, U.S. Environmental Protection Agency EPA-823/R-01-001 accessed February 8,2001 , at http:www.epa.gov/waterscience/criteria/methylmercury/document.html 1997, Mercury study report to Congress, Volume $\mathrm{V}$-Health effects of mercury and mercury compounds: U.S. Environmental Protection Agency EPA-452/R-97-007, 349 p. 1996a, Method 1669: Sampling ambient water for trace metals at EPA Water Quality Criteria levels (sampling guidance), U.S. Environmental Protection Agency EPA-821-B-96001 July 1996, 35 p. -1996b, Draft Method 1631: Mercury in water by oxidation, purge and trap, and cold vapor atomic flourescence spectrometry: U.S. Environmental Protection Agency EPA 821R-96-012, Office of Water, $32 \mathrm{p}$.

U.S. Geological Survey and U.S. Environmental Protection Agency, 2001, National Land Cover Dataset 30meter resolution based on 1992 Landsat thematic mapper imagery and supplemental data: URL http://landcover.usgs.gov

Wilde, F.D., and Radtke, D.B. (eds.), 1998, Field measurements-National field manual for the collection of water-quality data: U.S. Geological Survey Techniques of WaterResources Investigations book 9 , chap. A6, variously paged.

Wiener, J.G., and Spry, D.J., 1996, Toxicological significance of mercury in freshwater fish, in Beyer, W.N., Heinz, G.H., and Redmon, A.W., eds., Environmental contaminants in wildlife-Interpreting tissue concentrations: Boca Raton, Florida, Lewis Publishers, p. 297-339. 



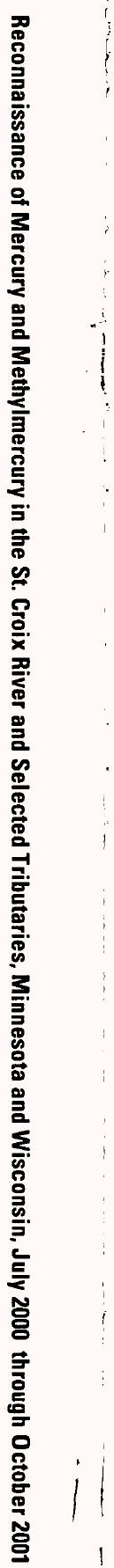

